\title{
Evaluation of Soft Tissue Measurements in Skeletal Class II Division I Malocclusion with Low Mandibular Plane Angel in Himachali Population: A Lateral Cephalometric Study
}

Dr. Ankur Sharma ${ }^{1}$, Dr. Aseem Sharma ${ }^{2 *}$, Dr. Apurva Vaidya ${ }^{3}$, Dr. Nandita Sood ${ }^{4}$, Dr. Ambuj Chandana ${ }^{5}$, Dr. Mandeep Phor $^{6}$

${ }^{1}$ M.D.S Orthodontics and Dentofacial Orthopedics and Ex Resident at Pt. J.L.N.G.M.C \& H Chamba Himachal Pradesh India

${ }^{2}$ M.D.S Orthodontics and Dentofacial Orthopedics and Senior Lecturer at Himachal Institute of Dental Sciences, Paonta Sahib Himachal Pradesh India

${ }^{3}$ Postgraduate Student in Department Of Pedodontics and Preventive Dentistry at Himachal Institute of Dental Sciences, Paonta Sahib Himachal Pradesh India

${ }^{4}$ M.D.S Orthodontics and Dentofacial Orthopedics and Senior Lecturer at Himachal Dental College Sunder Nagar, Himachal Pradesh India

${ }^{5}$ M.D.S Orthodontics and Dentofacial Orthopedics and Senior Lecturer at D.J Dental College Modinagar, Uttar Pradesh India

${ }^{6}$ Postgraduate Students in Department of Prosthodontics at DAV Dental College, Yamuna Nagar Haryana India

*Corresponding author: Dr. Aseem Sharma

\section{Abstract}

Aim: To evaluate the soft tissue characteristics of skeletal Class II Division 1 subjects (group II) with low mandibular plane angel compared with skeletal Class I subjects (group I) in himachali population. Material and Methods: Lateral cephalograms of 100 adults (60 women, 40 men; age range 18-50yrs) were divided into 2 groups based on horizontal and vertical skeletal pattern (SN-MP angle): group I, 50 subjects; group II-low angle $\left(<27^{\circ}\right)$, 50 subjects. The correlations and multiple linear regression tests were used to determine the skeletal and dental variables influencing soft tissue characteristics. Results: For the soft tissue analysis of all subjects, lower lip thickness was significantly increased in group II-L compared with group I. The perioral soft tissue measurements of group II were correlated with the inclination and anteroposterior position of the maxillary and mandibular incisors along with facial depth (N-Go) and facial length (S$\mathrm{Gn})$. Upper lip strain of group II was influenced by the inclination and anteroposterior position of the maxillary incisors. Conclusions: It is important to evaluate lip strain and lip thickness based on the skeletal pattern as well as dental inclination to obtain balance in the perioral muscle activity.

Keywords: Soft tissue evaluation, Class II division 1 malocclusion, cephalometry.

Copyright @ 2019: This is an open-access article distributed under the terms of the Creative Commons Attribution license which permits unrestricted use, distribution, and reproduction in any medium for non-commercial use (NonCommercial, or CC-BY-NC) provided the original author and source are credited.

\section{INTRODUCTION}

To maintain facial harmony along with occlusal excellence, it is necessary to determine the facial appearance by soft tissue analysis as well as underlying skeletal pattern in orthodontic treatment planning is necessary.

Riedel stated that the hard tissue profile outline bear harmonious relationship to patient's good profile [3]. It was found that lip position was closely correlated with the underlying dental and alveolar structures so an orthodontist can modify the position of teeth and alveolar structures to improve facial esthetics [4]. Soft tissue profiles can be influenced not only by skeletal pattern but also by dental position, and this is the focus with the characteristics of skeletal Class II Division1 in this study.
Sexual dimorphism, relative position and growth potential of the soft tissues of the nose, lips, and chin should be evaluated before any assessment of teeth and skeletal structures. Therefore, more objective soft tissue cephalometric guidelines providing reference values of overlying soft tissue thicknesses for each ethnic group would be requisite for enhanced treatment planning.

Also vertical growth pattern have different effect on different facial types and is changed by growth and by orthodontic treatment. This information is properly used to erase many of the adverse changes that are happening every day. The aims of this study were to determine the characteristics of soft tissues evaluation in Himachali adults with skeletal Class II Division 1 malocclusions according to low vertical Growth patterns compared with subjects with normal 
Ankur Sharma et al; Saudi J Oral Dent Res, Sep 2019; 4(9): 648-656

occlusion in skeletal Class I and to evaluate correlation of skeletal and dental variables affecting soft tissue thickness using cephalometric analysis.

\section{MATERIAL AND METHODS}

This study was conducted in the department of Orthodontics and Dentofacial Orthopaedics. The 100 subjects were divided into two groups.

GROUP I: Skeletal class I (control group)

GROUP II: Skeletal class II division I malocclusion with low Mandibular plane angle $(\mathrm{SN}-\mathrm{MP}<27)$

\section{The inclusion criteria for GROUP I were as follows}

- Skeletal class I malocclusion with class I molar and class I canine relation

- Normal overjet and normal overbite
- No missing teeth except third molar

- Absence of crowding

- No alteration of facial morphology

The inclusion criteria for GROUP II were as follows

- Skeletal class II malocclusion ( $\mathrm{ANB}>4$, Wits appraisal $>0$ and maxillary central incisor to SellaNasion,> 95 )

- Class II molar and class II canine relation

- Mild crowding ( arch length discrepancy <4 mm)

Lateral cephalograms were taken in natural head position and the patients were guided to close the lips in rest position. Lateral cephalograms were traced on acetate sheet. The following dental, skeletal and soft tissue measurements were done in different type of groups as shown in Table 1,

Table 2 and Table 3

Table-1: Showing dental measurements done on different types of malocclusion groups

\begin{tabular}{|l|l|}
\hline UI to $\mathrm{SN}\left({ }^{\circ}\right)$ & The angle formed by Sella-Nasion and the incisor long axis \\
\hline UI to NA( $\left(^{\circ}\right)$ & The angle formed between the long axes of the maxillary incisor to nasion - A point lines. \\
\hline $\begin{array}{l}\text { UI to } \\
\mathrm{NA}(\mathrm{mm})\end{array}$ & The linear distance from the most labial surface of incisor to the Nasion - A point line \\
\hline $\mathrm{LI}$ to $\mathrm{NB}\left({ }^{\circ}\right)$ & The angle formed between the long axis of the mandibular incisor to nasion - B point line. \\
\hline LI to NB $(\mathrm{mm})$ & The linear distance from the most labial surface of incisor to the Nasion - B point line \\
\hline IMPA & The inner angle between the long axis of the mandibular incisor and mandibular plane \\
\hline Overjet $(\mathrm{mm})$ & $\begin{array}{l}\text { The projection of the upper anterior teeth over their antagonists in a horizontal direction when the } \\
\text { mandible is in central relation. }\end{array}$ \\
\hline Overbite $(\mathrm{mm})$ & $\begin{array}{l}\text { The projection of the upper anterior teeth over the lower teeth in a vertical direction when posterior } \\
\text { teeth are in central occlusion. }\end{array}$ \\
\hline
\end{tabular}

Table-2: Showing skeletal measurements done on different types of malocclusion groups

\begin{tabular}{|l|l|}
\hline SN to MP $\left(^{\circ}\right)$ & $\begin{array}{l}\text { The angle formed between the anterior cranial base (S-N) to mandibular plane. (Drawn } \\
\text { between gonion }(\mathrm{Go}) \text { and gnathion }(\mathrm{Gn})) .\end{array}$ \\
\hline FMA $\left(^{\circ}\right)$ & $\begin{array}{l}\text { The angle formed between Frankfort horizontal plane and the line drawn along the lower } \\
\text { border of mandible through constructed gonion and menton }\end{array}$ \\
\hline SNA $\left(^{\circ}\right)$ & The angle between Sella-Nasion and Nasion-A point \\
\hline SNB $\left(^{\circ}\right)$ & $\begin{array}{l}\text { The angle formed between the Sella-Nasion and Nasion-B point } \\
\text { Planes }\end{array}$ \\
\hline ANB $\left(^{\circ}\right)$ & The difference between the SNA and SNB angles \\
\hline Wits $(\mathrm{mm})$ & $\begin{array}{l}\text { The perpendicular lines from points A and B on to the occlusal plane. The points of } \\
\text { contact are labeled AO and BO, respectively. }\end{array}$ \\
\hline Facial length $(\mathrm{mm})$ & Measured from Sella to Gnathion \\
\hline Facial depth $(\mathrm{mm})$ & Measured from Nasion to Gonion \\
\hline Facial height ratio $(\%)$ & Ratio of Sella-Gonion to nasion-menton(S-Go/N-Me) \\
\hline
\end{tabular}


Table-3: Showing soft tissue measurements done on different types of malocclusion groups

\begin{tabular}{|c|c|}
\hline $\begin{array}{l}\text { Basic upper lip } \\
\text { thickness (mm) }\end{array}$ & $\begin{array}{l}\text { linear distance from } 3 \mathrm{~mm} \\
\text { below A-point to subnasale }\end{array}$ \\
\hline $\begin{array}{l}\text { Upper lip thickness } \\
(\mathrm{mm})\end{array}$ & $\begin{array}{l}\text { Linear distance from the most prominent labial point of the } \\
\text { maxillary incisor (U1) to labrale superius (Ls) }\end{array}$ \\
\hline Upper lip strain (mm) & the difference between basic upper lip thickness and upper lip thickness \\
\hline $\begin{array}{l}\text { Lower lip thickness } \\
(\mathrm{mm})\end{array}$ & $\begin{array}{l}\text { linear distance from the most prominent labial point of the mandibular incisor (L1) to labrale } \\
\text { inferius (Li) }\end{array}$ \\
\hline $\begin{array}{l}\text { Basic lower lip } \\
\text { thickness (mm) }\end{array}$ & linear distance from B-point to the deepest point of the labiomental fold \\
\hline Chin thickness-H (mm) & linear distance from pogonion to its sagittal projection on the soft tissue (Pog-Pog') \\
\hline Chin thickness-V (mm) & linear distance from menton to its vertical projection on the soft tissue (Me-Me') \\
\hline $\begin{array}{l}\text { Subnasale to H-line } \\
(\mathrm{mm})\end{array}$ & Linear distance from subnasale to $\mathrm{H}$-line \\
\hline $\begin{array}{l}\text { Lower lip to H-line } \\
(\mathrm{mm})\end{array}$ & Linear distance from lower lip to H-line \\
\hline $\begin{array}{l}\text { Ricketts' E-line-upper } \\
(\mathrm{mm})\end{array}$ & Linear distance from vermilion border of upper lip to the $\mathrm{E}$ line \\
\hline $\begin{array}{l}\text { Ricketts' E-line-lower } \\
(\mathrm{mm})\end{array}$ & Linear distance from vermilion border of lower lip to the $\mathrm{E}$ line \\
\hline Upper lip length (mm) & $\begin{array}{l}\text { vertical distance from subnasale to the lowest point of the upper lip (Stms) perpendicular to } \\
\text { the Frankfort horizontal plane (FH plane) }\end{array}$ \\
\hline Lower lip length (mm) & $\begin{array}{l}\text { vertical distance from the highest point of the lower lip (Stmi) to the soft tissue B-point } \\
\text { perpendicular to the FH plane }\end{array}$ \\
\hline $\begin{array}{l}\text { Soft tissue contour } \\
(\mathrm{mm})\end{array}$ & total length of lower facial profile (subnasale-Me') \\
\hline $\begin{array}{l}\text { Hard tissue contour } \\
(\mathrm{mm})\end{array}$ & total length of hard tissue contour (anterior nasal spine-Me) \\
\hline Contour ratio $(\%)$ & Percentage ratio of soft tissue contour to hard tissue contour; \\
\hline Nasolabial angle $\left({ }^{\circ}\right)$ & $\begin{array}{l}\text { The angle formed by the intersection of the lines tangent to the columella of the nose and the } \\
\text { upper lip }\end{array}$ \\
\hline H-angle $\left(^{\circ}\right)$ & Angle formed by $\mathrm{H}$-line and soft tissue nasion-Pog0 line. \\
\hline
\end{tabular}

\section{STATISTICAL ANALYSIS}

SPSS version 15 computer program was used for the statistical analysis of the data. The statistical analyses included:

- Descriptive Statistics: Mean, standard deviation (SD), minimum, and maximum values.

- Inferential Statistics

- 1-way analysis of variance: comparison among groups

- Post hoc Scheff'e test: to analyze differences between the groups.

\section{RESULTS}

Table I Facial length (sella-gnathion) showed a significantly greater value in group I than in groups II. Facial depth (nasion-gonion) had a lower value in group I than in group II. The values for L1 to NB (in millimeters and degrees) were statistically lower in group I than in group II. Also, the values for L1 to NB (in millimeters and degrees) were significantly lower in group I than in groups II.

Table II. Lower lip length was significantly greater for groups I compared with group II. Also, there were statistical differences between groups in soft tissue contours, hard tissue contours and contour ratio.

Table III, The thickness of the perioral soft tissue was correlated with facial depth and facial length except for upper lip length. Also, basic lower lip thickness and lower lip length were correlated with SNMP and FMA. Basic upper lip thickness and upper lip thickness showed negative correlations with L1 to NB (degrees) with the highest coefficients. Upper lip strain showed correlations only with dental values, such as U1 to NA (millimeters and degrees), U1 to SN (degrees), and overjet. Basic upper lip thickness and basic lower lip thickness were correlated positively with most of the dental variables including L1 to NB (millimeters and degrees) and U1to NA (millimeters and degrees).

\section{DISCUSSION}

Soft tissue analysis is important in making orthodontic treatment planning and this can be achieved by knowing the effect of soft tissue in different skeletal classification. As the prevalence of Class II Division 1 malocclusion is high so in this study the soft tissue measurement of Class II Division 1 is considered for orthodontic treatment planning [28]. 
Ankur Sharma et al; Saudi J Oral Dent Res, Sep 2019; 4(9): 648-656

Previous studies have shown that the inclination of Mandibular plane affect the position of chin. Schudy and Isaacson et al. concluded in a study that Mandibular plane (SN-MP) has an effect on mandibular rotation as larger the SN-MP angle, the mandible tend to become steeper and more the chin moves backward, and vice versa [29-31].

In this study, most measurements of perioral soft tissue thickness were greater in men than in women. The basic upper lip thickness was significantly greater in men than in women in all groups. Kim $\mathrm{KH}$ et al. and Sung et al. found the same results of soft tissue measurement for both sexes [20, 32]. Kamak H et al. studied on Turkish population and concluded that lower lip thickness was greater in Class II skeletal pattern [15]. Lee et al. studied on Korean population and found that lower lip thickness was significantly greater in Class II Division 1 malocclusion with low and high Mandibular plane angle (SN-MP) compared with Class I skeletal malocclusion. In our study also lower lip thickness was significantly greater in group II compared with group I [20, 33]. In our study we found no significant difference in upper lip length between groups I and II. This is in correlation with the study done by Lee et al. in Korean population.

In study done by Lee et al. on Turkish population, they found that basic lower lip thickness was significantly greater in class II Division 1 with high SN-MP angle compared between Class II division 1 with low and normal SN-MP angle and Class I malooclusion [21]. Our study found no significant difference between group I and group II. This is due to the compensation of the soft tissue for the high SN-MP skeletal pattern. Blanchette et al. stated that this may have been a natural phenomenon that compensates for the shorter Mandibular corpus length in order to mask the condition and providing a more normal facial appearance. Conversely the short vertical pattern showed a smaller basic lower lip thickness as a result of deficiency of vertical skeletal growth [21].

According to Holdaway[3], upper lip strain is difference between basic upper lip thickness and upper lip thickness and was useful in determining the amount of lip strain or incompetency. Holdaway suggested that the upper lip strain of $1 \mathrm{~mm}$ or less would be acceptable and excess of it result in thinning of upper lip as it is stretched over the protrusive teeth. Therefore, we can achieve acceptable upper lip strain by controlling the incisors to eliminate the lip strain. By correlating results of group II statistically correlation was seen in upper lip strain with UI/NA (degree and $\mathrm{mm}$ ) and UI/SN (degree). The upper lip strain observed in range (2.0 \pm 1.3 , and $3.04 \pm 0.83 \mathrm{~mm}$ for groups I and II) in our study groups which was influenced by proclination and saggital position of upper incisors. Thus, presumption of soft tissue change rather is based on dental characteristics of upper incisors instead of vertical pattern of mandible.

In this study we found that the value for L1 to NB (degrees) had a statistically greater value compared with group I and this might be because of the compensating effort. Lip strain needs to be evaluated carefully depending on the sagittal position of the mandibular incisors because an increased value of U1 to NA (degrees) can affect upper lip strain in Class II patients.

In our study the sample comprises of male and female group was too small to calculate the statistical power separately. Therefore, larger sample and additional skeletal classification (eg, Class II Division 2 or Class III) in comparative studies should be done to increase the scientific and statistical power. The pre and post orthodontic treatment changes of perioral soft tissues should be considered as well.

Several studies have been done in different races to evaluate the soft tissue thickness [39] and found variation among races for example soft tissue thickness variation among African Americans and white Americans, Saudi Arabians and white people [40, 41]. Therefore, the thickness characteristic of this study is limited to Himachali population, and future research should consider racial differences when validating our results. We found certain limitation in investigating the soft tissue because of the reliability of obtaining a relaxed lip profile radiographically. Even though the radiographs were taken with the lips closed for adequate lip thickness and lip strain conditions, a strained lip position could occur because of muscle hyperactivity from chin prominence. As posteroanterior radiographs or frontal facial photographs were not available so we did not include transverse measurements as it may affect soft tissue thickness. Within the limitations of this study, it can be concluded that perioral soft tissue characteristics of skeletal Class II Division 1 subjects showed significant differences according to sagittal and vertical skeletal patterns and were influenced by anteroposterior positions and the inclination of the incisors along with facial depth and facial length. Therefore, clinicians should evaluate lip strain and lip thickness based on the skeletal pattern as well as the dental inclination to establish the treatment objectives for a balanced facial profile.

\section{CONCLUSIONS}

- The basic lower lip thickness and lower lip length had significantly greater values in Class II Division 1 malocclusion as compared to class I skeletal malocclusion in Himachali polulation.

- The measurements of soft tissue thickness were related with the inclination and the anteroposterior position of the upper and lower incisors along with 
Ankur Sharma et al; Saudi J Oral Dent Res, Sep 2019; 4(9): 648-656

facial depth and facial length in skeletal Class II subjects.

- In the skeletal Class II subjects, upper lip strain was influenced by the inclination and the anteroposterior position of the maxillary incisors.
- Clinicians need to evaluate lip strain and lip thickness based on the skeletal pattern as well as dental inclination to obtain balance in the perioral muscle activity.

Table-I: Skeletal and dental measurements (means and standard deviations) for all subjects

\begin{tabular}{|c|c|c|c|c|c|c|c|c|c|}
\hline \multicolumn{10}{|c|}{ Descriptives } \\
\hline & & \multirow[t]{2}{*}{$\mathbf{N}$} & \multirow[t]{2}{*}{ Mean } & \multirow[t]{2}{*}{$\begin{array}{l}\text { Std. } \\
\text { Deviation }\end{array}$} & \multirow[t]{2}{*}{$\begin{array}{l}\text { Std. } \\
\text { Error }\end{array}$} & \multicolumn{2}{|c|}{$\begin{array}{l}\text { 95\% Confidence Interval for } \\
\text { Mean }\end{array}$} & \multirow[t]{2}{*}{ Minimum } & \multirow[t]{2}{*}{ Maximum } \\
\hline & & & & & & Lower Bound & Upper Bound & & \\
\hline \multirow[t]{2}{*}{ SN/MP } & $\mathrm{I}$ & 26 & 31.00 & 2.349 & .461 & 30.05 & 31.95 & 28 & 35 \\
\hline & $\begin{array}{l}\text { II } \\
\mathrm{L}\end{array}$ & 26 & 24.92 & .744 & .146 & 24.62 & 25.22 & 24 & 26 \\
\hline \multirow[t]{2}{*}{ FMA } & $\mathrm{I}$ & 26 & 26.88 & 1.177 & .231 & 26.41 & 27.36 & 25 & 29 \\
\hline & $\begin{array}{l}\text { II } \\
\mathrm{L}\end{array}$ & 26 & 20.19 & 1.443 & .283 & 19.61 & 20.78 & 16 & 22 \\
\hline \multirow[t]{2}{*}{ SNA } & $\mathrm{I}$ & 26 & 82.27 & 1.888 & .370 & 81.51 & 83.03 & 79 & 85 \\
\hline & $\begin{array}{l}\text { II } \\
\mathrm{L}\end{array}$ & 26 & 82.00 & 2.191 & .430 & 81.12 & 82.88 & 79 & 85 \\
\hline \multirow[t]{2}{*}{ SNB } & $\mathrm{I}$ & 26 & 80.12 & 1.505 & .295 & 79.51 & 80.72 & 77 & 82 \\
\hline & $\begin{array}{l}\text { II } \\
\mathrm{L}\end{array}$ & 26 & 79.00 & .000 & .000 & 79.00 & 79.00 & 79 & 79 \\
\hline \multirow[t]{2}{*}{ ANB } & $\mathrm{I}$ & 26 & 2.15 & .613 & .120 & 1.91 & 2.40 & 1 & 3 \\
\hline & $\begin{array}{l}\text { II } \\
\mathrm{L}\end{array}$ & 26 & 5.77 & 1.070 & .210 & 5.34 & 6.20 & 5 & 8 \\
\hline \multirow[t]{2}{*}{ WITTS } & $\mathrm{I}$ & 26 & .92 & .628 & .123 & .67 & 1.18 & 0 & 2 \\
\hline & $\begin{array}{l}\text { II } \\
\mathrm{L}\end{array}$ & 26 & 4.88 & 1.505 & .295 & 4.28 & 5.49 & 2 & 7 \\
\hline \multirow[t]{2}{*}{ FC. LEN. } & $\mathrm{I}$ & 26 & 130.50 & 4.411 & .865 & 128.72 & 132.28 & 124 & 138 \\
\hline & $\begin{array}{l}\text { II } \\
\mathrm{L}\end{array}$ & 26 & 122.77 & 2.303 & .452 & 121.84 & 123.70 & 117 & 125 \\
\hline \multirow[t]{2}{*}{ FCDEP } & $\mathrm{I}$ & 26 & 121.23 & 4.264 & .836 & 119.51 & 122.95 & 116 & 128 \\
\hline & $\begin{array}{l}\text { II } \\
\mathrm{L}\end{array}$ & 26 & 126.92 & 4.363 & .856 & 125.16 & 128.69 & 118 & 132 \\
\hline \multirow[t]{2}{*}{$\operatorname{FHR}(\%)$} & $\mathrm{I}$ & 26 & 64.9000 & 11.83734 & 2.32149 & 60.1188 & 69.6812 & 8.00 & 70.87 \\
\hline & $\begin{array}{l}\text { II } \\
\mathrm{L}\end{array}$ & 26 & 71.3358 & 1.66598 & .32673 & 70.6629 & 72.0087 & 69.03 & 74.36 \\
\hline \multirow[t]{2}{*}{ UI/SN } & I & 26 & 104.35 & 1.129 & .221 & 103.89 & 104.80 & 103 & 108 \\
\hline & $\begin{array}{l}\text { II } \\
\mathrm{L}\end{array}$ & 26 & 106.08 & 5.098 & 1.000 & 104.02 & 108.14 & 96 & 115 \\
\hline \multirow[t]{2}{*}{ UI/NA } & $\mathrm{I}$ & 26 & 23.62 & 1.878 & .368 & 22.86 & 24.37 & 20 & 26 \\
\hline & $\begin{array}{l}\text { II } \\
\mathrm{L}\end{array}$ & 26 & 25.58 & 4.751 & .932 & 23.66 & 27.50 & 18 & 32 \\
\hline \multirow{2}{*}{$\begin{array}{l}\mathrm{UI} / \mathrm{NA} \\
\mathrm{mm}\end{array}$} & $\mathrm{I}$ & 26 & 5.31 & .736 & .144 & 5.01 & 5.60 & 4 & 6 \\
\hline & $\begin{array}{l}\text { II } \\
\mathrm{L} \\
\end{array}$ & 26 & 6.19 & 1.096 & .215 & 5.75 & 6.64 & 4 & 8 \\
\hline \multirow[t]{2}{*}{$\mathrm{LI} / \mathrm{NB}$} & $\mathrm{I}$ & 26 & 24.69 & 1.828 & .358 & 23.95 & 25.43 & 22 & 29 \\
\hline & $\begin{array}{l}\text { II } \\
\mathrm{L}\end{array}$ & 26 & 28.42 & 2.610 & .512 & 27.37 & 29.48 & 23 & 36 \\
\hline \multirow[t]{2}{*}{$\mathrm{LI} / \mathrm{NB} \mathrm{mm}$} & $\mathrm{I}$ & 26 & 5.19 & .895 & .176 & 4.83 & 5.55 & 4 & 7 \\
\hline & $\begin{array}{l}\text { II } \\
\mathrm{L}\end{array}$ & 26 & 6.54 & 1.104 & .216 & 6.09 & 6.98 & 5 & 8 \\
\hline \multirow[t]{2}{*}{ IMPA } & $\mathrm{I}$ & 26 & 93.77 & 1.861 & .365 & 93.02 & 94.52 & 91 & 97 \\
\hline & $\begin{array}{l}\text { II } \\
\mathrm{L}\end{array}$ & 26 & 100.46 & 4.264 & .836 & 98.74 & 102.18 & 92 & 108 \\
\hline
\end{tabular}


Ankur Sharma et al; Saudi J Oral Dent Res, Sep 2019; 4(9): 648-656

Table-II: Soft tissue analysis of all subjects (means and standard deviations)

\begin{tabular}{|c|c|c|c|c|c|c|c|c|c|}
\hline \multicolumn{10}{|c|}{ Descriptives } \\
\hline & & \multirow[t]{2}{*}{$\mathrm{N}$} & \multirow[t]{2}{*}{ Mean } & \multirow[t]{2}{*}{$\begin{array}{l}\text { Std. } \\
\text { Deviation }\end{array}$} & \multirow[t]{2}{*}{$\begin{array}{l}\text { Std. } \\
\text { Error }\end{array}$} & \multicolumn{2}{|c|}{$\begin{array}{l}\text { 95\% Confidence Interval for } \\
\text { Mean }\end{array}$} & \multirow[t]{2}{*}{ Minimum } & \multirow[t]{2}{*}{ Maximum } \\
\hline & & & & & & Lower Bound & Upper Bound & & \\
\hline \multirow{2}{*}{$\begin{array}{l}\text { BASIC UPPER LIP } \\
\text { THICKNES }\end{array}$} & $\mathrm{I}$ & 26 & 17.15 & 2.222 & .436 & 16.26 & 18.05 & 15 & 21 \\
\hline & $\begin{array}{l}\text { II } \\
\text { L }\end{array}$ & 26 & 16.85 & .967 & .190 & 16.46 & 17.24 & 15 & 18 \\
\hline \multirow[t]{2}{*}{ UPPER LIP THICKNES } & $\mathrm{I}$ & 26 & 15.15 & 2.962 & .581 & 13.96 & 16.35 & 12 & 20 \\
\hline & $\begin{array}{l}\text { II } \\
\mathrm{L}\end{array}$ & 26 & 13.81 & 1.443 & .283 & 13.22 & 14.39 & 10 & 15 \\
\hline \multirow[t]{2}{*}{ UPPER LIP STRAIN } & $\mathrm{I}$ & 26 & 2.00 & 1.356 & .266 & 1.45 & 2.55 & 0 & 5 \\
\hline & $\begin{array}{l}\text { II } \\
\text { L }\end{array}$ & 26 & 3.04 & .824 & .162 & 2.71 & 3.37 & 2 & 5 \\
\hline \multirow{2}{*}{ LOWER LIP THICKNES } & $\mathrm{I}$ & 26 & 16.42 & 2.533 & .497 & 15.40 & 17.45 & 13 & 21 \\
\hline & $\begin{array}{l}\text { II } \\
\mathrm{L}\end{array}$ & 26 & 16.85 & .925 & .181 & 16.47 & 17.22 & 15 & 18 \\
\hline \multirow{2}{*}{$\begin{array}{l}\text { BASIC LOWER LIP } \\
\text { THICKNES }\end{array}$} & $\mathrm{I}$ & 26 & 12.58 & 1.793 & .352 & 11.85 & 13.30 & 10 & 15 \\
\hline & $\begin{array}{l}\text { II } \\
\mathrm{L}\end{array}$ & 26 & 12.62 & .941 & .185 & 12.24 & 13.00 & 11 & 14 \\
\hline \multirow[t]{2}{*}{ CHIN THICKNESS H } & $\mathrm{I}$ & 26 & 12.85 & 2.034 & .399 & 12.02 & 13.67 & 8 & 16 \\
\hline & $\begin{array}{l}\text { II } \\
\mathrm{L}\end{array}$ & 26 & 13.15 & 1.434 & .281 & 12.57 & 13.73 & 11 & 15 \\
\hline \multirow[t]{2}{*}{ CHIN THICKNES V } & $\mathrm{I}$ & 26 & 7.62 & .898 & .176 & 7.25 & 7.98 & 6 & 10 \\
\hline & $\begin{array}{l}\text { II } \\
\mathrm{L}\end{array}$ & 26 & 7.54 & .508 & .100 & 7.33 & 7.74 & 7 & 8 \\
\hline \multirow[t]{2}{*}{ SUBSNAL H-LINE } & $\mathrm{I}$ & 26 & 5.42 & 1.629 & .319 & 4.77 & 6.08 & 3 & 9 \\
\hline & $\begin{array}{l}\text { II } \\
\mathrm{L} \\
\end{array}$ & 26 & 3.73 & 1.002 & .197 & 3.33 & 4.14 & 2 & 5 \\
\hline \multirow[t]{2}{*}{ LOWER LIP H-LINE } & $\mathrm{I}$ & 26 & -1.15 & 1.461 & .287 & -1.74 & -.56 & -4 & 2 \\
\hline & $\begin{array}{l}\text { II } \\
\mathrm{L}\end{array}$ & 26 & -.92 & 2.038 & .400 & -1.75 & -.10 & -3 & 3 \\
\hline \multirow[t]{2}{*}{ RIKKETS E-LINE UPPER } & $\mathrm{I}$ & 26 & 3.73 & 2.164 & .424 & 2.86 & 4.60 & 0 & 8 \\
\hline & $\begin{array}{l}\text { II } \\
\mathrm{L} \\
\end{array}$ & 26 & 5.08 & 1.853 & .363 & 4.33 & 5.83 & 2 & 8 \\
\hline \multirow[t]{2}{*}{ RIKKETS E-LINE LOWER } & $\mathrm{I}$ & 26 & 1.04 & 1.800 & .353 & .31 & 1.77 & -3 & 5 \\
\hline & $\begin{array}{l}\text { II } \\
\mathrm{L}\end{array}$ & 26 & 1.15 & 1.488 & .292 & .55 & 1.76 & -1 & 4 \\
\hline \multirow[t]{2}{*}{ UPPER LIP LENGTH } & $\mathrm{I}$ & 26 & 20.92 & 1.573 & .308 & 20.29 & 21.56 & 17 & 23 \\
\hline & $\begin{array}{l}\text { II } \\
\mathrm{L}\end{array}$ & 26 & 19.69 & 1.490 & .292 & 19.09 & 20.29 & 17 & 21 \\
\hline \multirow[t]{2}{*}{ LOWER LIP LENGTH } & $\mathrm{I}$ & 26 & 18.65 & 1.231 & .241 & 18.16 & 19.15 & 17 & 21 \\
\hline & $\begin{array}{l}\text { II } \\
\mathrm{L}\end{array}$ & 26 & 16.88 & .816 & .160 & 16.55 & 17.21 & 16 & 19 \\
\hline \multirow[t]{2}{*}{ SOFT TISSUE CONTOUR } & $\mathrm{I}$ & 26 & 74.42 & 2.996 & .587 & 73.21 & 75.63 & 68 & 79 \\
\hline & $\begin{array}{l}\text { II } \\
\mathrm{L}\end{array}$ & 26 & 71.19 & 2.654 & .520 & 70.12 & 72.26 & 67 & 75 \\
\hline \multirow[t]{2}{*}{ HARD TISSUE CONTOUR } & $\mathrm{I}$ & 26 & 70.35 & 3.463 & 679 & 68.95 & 71.75 & 66 & 76 \\
\hline & $\begin{array}{l}\text { II } \\
\mathrm{L} \\
\end{array}$ & 26 & 65.08 & 3.249 & .637 & 63.76 & 66.39 & 60 & 70 \\
\hline \multirow[t]{2}{*}{ NASOBIAL ANGLE } & $\mathrm{I}$ & 26 & 106.42 & 7.256 & 1.423 & 103.49 & 109.35 & 95 & 120 \\
\hline & $\begin{array}{l}\text { II } \\
\mathrm{L}\end{array}$ & 26 & 107.81 & 9.108 & 1.786 & 104.13 & 111.49 & 96 & 122 \\
\hline \multirow[t]{2}{*}{ H-ANGLE } & $\mathrm{I}$ & 26 & 16.31 & 4.389 & .861 & 14.54 & 18.08 & 10 & 24 \\
\hline & $\begin{array}{l}\text { II } \\
\mathrm{L} \\
\end{array}$ & 26 & 18.15 & 2.962 & .581 & 16.96 & 19.35 & 15 & 24 \\
\hline CONTOR RATIO (\%) & $\mathrm{I}$ & 26 & $1.0588 \mathrm{E} 2$ & 3.18178 & .62400 & 104.5945 & 107.1648 & 98.55 & 112.12 \\
\hline & $\begin{array}{l}\text { II } \\
\mathrm{L}\end{array}$ & 26 & $1.0947 \mathrm{E} 2$ & 1.91791 & .37613 & 108.6956 & 110.2449 & 107.14 & 114.06 \\
\hline
\end{tabular}


Ankur Sharma et al; Saudi J Oral Dent Res, Sep 2019; 4(9): 648-656

Table-III: Pearson correlation coefficients of group II between soft tissue thickness and skeletal and dental variables

\begin{tabular}{|c|c|c|c|c|c|c|c|c|c|c|c|c|c|c|c|c|c|c|c|}
\hline & & $\begin{array}{l}\text { BASI } \\
\text { C } \\
\text { UPPE } \\
\text { R LIP } \\
\text { THIC } \\
\text { KNE } \\
\text { S }\end{array}$ & $\begin{array}{l}\text { UPPE } \\
\text { R LIP } \\
\text { THIC } \\
\text { KNE } \\
\mathrm{S}\end{array}$ & $\begin{array}{l}\text { UP } \\
\text { PE } \\
\text { R } \\
\text { LIP } \\
\text { ST } \\
\text { RAI } \\
\text { N }\end{array}$ & $\begin{array}{l}\text { LOE } \\
\text { R LIP } \\
\text { THIC } \\
\text { KNE } \\
\mathrm{S}\end{array}$ & $\begin{array}{l}\text { BASI } \\
\text { C } \\
\text { LOW } \\
\text { ER } \\
\text { LIP } \\
\text { THIC } \\
\text { KNE } \\
\text { S }\end{array}$ & $\begin{array}{l}\text { CHIN } \\
\text { THICK } \\
\text { NES H }\end{array}$ & $\begin{array}{l}\text { CH } \\
\text { IN } \\
\text { THI } \\
\text { CK } \\
\text { NE } \\
\text { S V }\end{array}$ & $\begin{array}{l}\text { SUBSN } \\
\text { AL H- } \\
\text { LINE }\end{array}$ & $\begin{array}{l}\text { LO } \\
\text { WE } \\
\text { R } \\
\text { LIP } \\
\text { H- } \\
\text { LIN } \\
\text { E }\end{array}$ & $\begin{array}{l}\text { RIK } \\
\text { KET } \\
\text { S E- } \\
\text { LIN } \\
\text { E } \\
\text { UPP } \\
\text { ER }\end{array}$ & $\begin{array}{l}\text { RIKK } \\
\text { ETS } \\
\text { E- } \\
\text { LINE } \\
\text { LOW } \\
\text { ER }\end{array}$ & $\begin{array}{l}\text { UPPE } \\
\text { R LIP } \\
\text { LEN } \\
\text { GTH }\end{array}$ & $\begin{array}{l}\text { LOW } \\
\text { ER } \\
\text { LIP } \\
\text { LEN } \\
\text { GTH }\end{array}$ & $\begin{array}{l}\text { SOFT } \\
\text { TISSUE } \\
\text { CONT } \\
\text { OUR }\end{array}$ & $\begin{array}{l}\text { HARD } \\
\text { TISSUE } \\
\text { CONT } \\
\text { OUR }\end{array}$ & $\begin{array}{l}\text { NAS } \\
\text { OBIA } \\
\text { L } \\
\text { ANG } \\
\text { LE }\end{array}$ & $\begin{array}{l}\text { H- } \\
\text { ANGL } \\
\text { E }\end{array}$ & $\begin{array}{l}\text { CON } \\
\text { TOR } \\
\text { RAT } \\
\text { IO } \\
(\%)\end{array}$ \\
\hline \multirow[t]{3}{*}{ SNMP } & $\mathrm{R}$ & -.132 & -.123 & $\begin{array}{l}- \\
.07 \\
8\end{array}$ & $-.426^{\prime \prime}$ & -.358 & $\begin{array}{l}.096 \\
\end{array}$ & $\begin{array}{l}.15 \\
6\end{array}$ & $.521^{* * m}$ & .362 & $.432^{\prime \prime}$ & .304 & -.197 & .193 & $-.401^{n}$ & $-.438^{\circ}$ & $\begin{array}{l}-.029 \\
\end{array}$ & $\begin{array}{l}.014 \\
\end{array}$ & $.402^{\prime \prime}$ \\
\hline & $P$ & .520 & .549 & $\begin{array}{l}70 \\
6\end{array}$ & .030 & .073 & .643 & $\begin{array}{l}.44 \\
8\end{array}$ & .006 & .069 & .028 & .132 & .335 & .344 & .043 & .025 & .887 & $\begin{array}{l}.944 \\
\end{array}$ & .042 \\
\hline & $\mathrm{N}$ & 26 & 26 & 26 & 26 & 26 & 26 & 26 & 26 & 26 & 26 & 26 & 26 & 26 & 26 & 26 & 26 & 26 & 26 \\
\hline \multirow[t]{3}{*}{$\overline{\text { FMA }}$} & $\mathrm{R}$ & -.249 & .005 & $\begin{array}{l}.23 \\
4\end{array}$ & -.089 & -.284 & .140 & $\begin{array}{l}.23 \\
3\end{array}$ & .267 & .312 & $.497^{*}$ & .258 & -.060 & .041 & -.188 & -347 & -.123 & -.014 & $.432^{\circ}$ \\
\hline & $P$ & .219 & .979 & $\begin{array}{l}.24 \\
9\end{array}$ & .664 & .159 & .495 & $\begin{array}{l}.25 \\
1\end{array}$ & .188 & .121 & .010 & .204 & .772 & .844 & .357 & .082 & .550 & .946 & .027 \\
\hline & $\mathrm{N}$ & 26 & 26 & 26 & 26 & 26 & 26 & 26 & 26 & 26 & 26 & 26 & 26 & 26 & 26 & 26 & 26 & 26 & 26 \\
\hline \multirow[t]{3}{*}{ SNA } & $\mathrm{R}$ & -.084 & -.092 & $\begin{array}{l}- \\
.04 \\
5\end{array}$ & .102 & -.387 & $\begin{array}{l}.056 \\
\end{array}$ & $\begin{array}{l}- \\
.31 \\
6\end{array}$ & .199 & $\begin{array}{l}.044 \\
.04\end{array}$ & .210 & -.142 & $.614^{* 7 "}$ & $-\overline{-} .582^{* *}$ & -.141 & $\begin{array}{l}-.146 \\
\end{array}$ & .384 & $.529^{9 * 7}$ & .124 \\
\hline & $P$ & .682 & $\begin{array}{l}.654 \\
\end{array}$ & $\begin{array}{l}.82 \\
8 \\
\end{array}$ & .619 & .051 & .786 & $\begin{array}{l}.11 \\
6 \\
\end{array}$ & .329 & .832 & .302 & .490 & .001 & .002 & .491 & .476 & .052 & .005 & $\begin{array}{l}.547 \\
\end{array}$ \\
\hline & $\mathrm{N}$ & 26 & 26 & 26 & 26 & 26 & 26 & 26 & 26 & 26 & 26 & 26 & 26 & 26 & 26 & 26 & 26 & 26 & 26 \\
\hline \multirow[t]{3}{*}{ SNB } & $\mathrm{R}$ & -.080 & -.077 & $\begin{array}{l}-. \\
.04 \\
6\end{array}$ & .091 & $-.408^{\prime \prime}$ & -.083 & $\begin{array}{l}-27 \\
8\end{array}$ & .217 & .006 & .289 & -.081 & $.561^{\prime \prime \prime}$ & $.548^{* * *}$ & -.244 & -.246 & $.413^{\prime \prime}$ & $.479^{\prime \prime}$ & .208 \\
\hline & $P$ & .698 & .709 & $\begin{array}{l}.82 \\
3\end{array}$ & .660 & $\begin{array}{l}.038 \\
\end{array}$ & .686 & $\begin{array}{l}.16 \\
9\end{array}$ & .286 & .976 & .152 & .696 & .003 & .004 & .231 & .225 & .036 & .013 & .308 \\
\hline & $\mathrm{N}$ & 26 & 26 & 26 & 26 & 26 & 26 & 26 & 26 & 26 & 26 & 26 & 26 & 26 & 26 & 26 & 26 & 26 & 26 \\
\hline \multirow[t]{3}{*}{$\overline{\mathrm{ANB}}$} & $\mathrm{R}$ & .019 & -.049 & $\begin{array}{l}.03 \\
6\end{array}$ & .020 & .372 & .218 & $\begin{array}{l}- \\
.07 \\
2\end{array}$ & -.240 & .229 & $-657^{*}$ & -.331 & .000 & .111 & $.776^{\prime \prime \prime}$ & $.765^{\prime \prime \prime}$ & $-.417^{\prime \prime}$ & .024 & $.644^{*}$ \\
\hline & $P$ & .926 & .814 & $\begin{array}{l}.86 \\
2 \\
\end{array}$ & .922 & .061 & .285 & $\begin{array}{l}.72 \\
8 \\
\end{array}$ & .238 & .261 & .000 & .098 & 1.000 & .591 & .000 & .000 & .034 & .908 & .000 \\
\hline & $\mathrm{N}$ & 26 & 26 & 26 & 26 & 26 & 26 & 26 & 26 & 26 & 26 & 26 & 26 & 26 & 26 & 26 & 26 & 26 & 26 \\
\hline \multirow[t]{3}{*}{ WITTS } & $\mathrm{R}$ & .090 & .004 & $\begin{array}{l}.08 \\
2\end{array}$ & -.002 & .017 & -.075 & $\begin{array}{l}.45 \\
3^{*}\end{array}$ & .022 & .364 & $.607^{*}$ & $.453^{\prime \prime}$ & $.500^{* * *}$ & .254 & $-.656^{\prime \prime \prime}$ & -.712 "'t" & -.030 & -.326 & $.659^{*}$ \\
\hline & $P$ & .661 & .983 & $\begin{array}{l}.68 \\
9\end{array}$ & .993 & .936 & .716 & $\begin{array}{l}.02 \\
0\end{array}$ & .915 & .068 & .001 & .020 & .009 & .210 & .000 & .000 & .886 & .104 & .000 \\
\hline & $\mathrm{N}$ & 26 & 26 & 26 & 26 & 26 & 26 & 26 & 26 & 26 & 26 & 26 & 26 & 26 & 26 & 26 & 26 & 26 & 26 \\
\hline \multirow[t]{3}{*}{$\begin{array}{l}\text { FC. } \\
\text { LEN. }\end{array}$} & $\mathrm{R}$ & -.156 & -.018 & $\begin{array}{l}- \\
.13 \\
9 \\
\end{array}$ & -.326 & -.242 & -.261 & $\begin{array}{l}- \\
.29 \\
7 \\
\end{array}$ & .217 & .138 & .105 & -.003 & -.280 & .299 & -.278 & -.230 & .192 & $-.533^{m+m}$ & .164 \\
\hline & $P$ & .445 & .930 & $\begin{array}{l}49 \\
8\end{array}$ & .104 & .233 & .199 & $\begin{array}{l}.14 \\
0\end{array}$ & .288 & .501 & .609 & .988 & .166 & .138 & .169 & .258 & .347 & .005 & .422 \\
\hline & $\mathrm{N}$ & 26 & 26 & 26 & 26 & 26 & 26 & 26 & 26 & 26 & 26 & 26 & 26 & 26 & 26 & 26 & 26 & 26 & 26 \\
\hline \multirow[t]{3}{*}{ FCDEP } & $\mathrm{R}$ & -.009 & -.102 & $\begin{array}{l}.02 \\
9\end{array}$ & .180 & $.507^{\prime \prime \prime}$ & -.119 & $\begin{array}{l}.16 \\
7\end{array}$ & $-.644^{\prime \prime \prime}$ & $\begin{array}{l}-. \\
.090\end{array}$ & -.364 & -.036 & -.177 & .075 & .365 & $.462^{\prime \prime}$ & $-.394^{\prime \prime}$ & -.308 & $.473^{*}$ \\
\hline & $P$ & .966 & $\begin{array}{l}.622 \\
\end{array}$ & $\begin{array}{l}.88 \\
7\end{array}$ & .378 & .008 & .562 & $\begin{array}{l}.41 \\
6\end{array}$ & .000 & .663 & .068 & .861 & .386 & .717 & .067 & .017 & .047 & .126 & .015 \\
\hline & $\mathrm{N}$ & 26 & 26 & 26 & 26 & 26 & 26 & 26 & 26 & 26 & 26 & 26 & 26 & 26 & 26 & 26 & 26 & 26 & 26 \\
\hline \multirow[t]{3}{*}{$\begin{array}{l}\text { FHR(\% } \\
)\end{array}$} & $\mathrm{R}$ & $\begin{array}{l}.009 \\
\end{array}$ & -.126 & $\begin{array}{l}.03 \\
9\end{array}$ & .097 & $\begin{array}{l}.373 \\
\end{array}$ & .041 & $\begin{array}{l}.05 \\
7\end{array}$ & \begin{tabular}{c|}
.288 \\
\end{tabular} & $\begin{array}{l}-.179 \\
.179\end{array}$ & $\begin{array}{l}- \\
\end{array} 600^{*}$ & $\begin{array}{l}-235 \\
\end{array}$ & $\begin{array}{l}.034 \\
\end{array}$ & .060 & $.670^{\prime \prime \prime \prime}$ & $.725^{\prime \prime \prime}$ & $.540^{n * *}$ & .076 & $-668^{*}$ \\
\hline & $P$ & .967 & .539 & $\begin{array}{l}.85 \\
2\end{array}$ & .638 & .061 & .842 & $\begin{array}{l}.78 \\
3\end{array}$ & .153 & .382 & .001 & .248 & .869 & .770 & .000 & .000 & .004 & .711 & .000 \\
\hline & $\mathrm{N}$ & 26 & 26 & 26 & 26 & 26 & 26 & 26 & 26 & 26 & 26 & 26 & 26 & 26 & 26 & 26 & 26 & 26 & 26 \\
\hline \multirow[t]{3}{*}{ UI/SN } & $\mathrm{R}$ & $.410^{\circ}$ & -.087 & $\begin{array}{l}41 \\
4\end{array}$ & -.287 & .185 & .184 & $\begin{array}{l}.37 \\
5\end{array}$ & -.237 & .312 & $\begin{array}{l}.212 \\
\end{array}$ & $\begin{array}{l}-255 \\
\end{array}$ & $.541^{\mathrm{m}}$ & $-.597^{* *}$ & $\begin{array}{l}-230 \\
\end{array}$ & -.314 & .133 & .359 & $\begin{array}{l}.341 \\
\end{array}$ \\
\hline & $P$ & .037 & $\begin{array}{l}.673 \\
\end{array}$ & $\begin{array}{l}.03 \\
6 \\
\end{array}$ & .155 & .366 & .369 & $\begin{array}{l}.05 \\
9 \\
\end{array}$ & .243 & .120 & .299 & .209 & .004 & .001 & .259 & .119 & .517 & .072 & .088 \\
\hline & $\mathrm{N}$ & 26 & 26 & 26 & 26 & 26 & 26 & 26 & 26 & 26 & 26 & 26 & 26 & 26 & 26 & 26 & 26 & 26 & 26 \\
\hline \multirow[t]{3}{*}{ UI/NA } & $\mathrm{R}$ & $.514^{2 * *}$ & -.081 & $\begin{array}{l}.50 \\
.50 \\
9^{* *+1}\end{array}$ & -.343 & .381 & .057 & $\begin{array}{l}- \\
.36 \\
3\end{array}$ & -.334 & .205 & -.056 & $\begin{array}{l}00 \\
-.270\end{array}$ & .307 & $\begin{array}{l}-.0 \\
-.357\end{array}$ & $\frac{-1147}{-.147}$ & $\frac{-1.0}{-.125}$ & .158 & .172 & .089 \\
\hline & $P$ & $\begin{array}{l}.007 \\
\end{array}$ & $\begin{array}{l}.694 \\
\end{array}$ & $\begin{array}{l}.00 \\
8\end{array}$ & $\begin{array}{l}.086 \\
\end{array}$ & .055 & .782 & $\begin{array}{l}.06 \\
8\end{array}$ & .095 & .315 & .786 & .183 & .127 & .073 & .475 & .543 & .440 & .401 & .667 \\
\hline & $\mathrm{N}$ & 26 & 26 & 26 & 26 & 26 & 26 & 26 & 26 & 26 & 26 & 26 & 26 & 26 & 26 & 26 & 26 & 26 & 26 \\
\hline \multirow[t]{3}{*}{$\begin{array}{l}\text { UI/NA } \\
\mathrm{mm}\end{array}$} & $\mathrm{R}$ & $.437^{\circ}$ & -.293 & $\begin{array}{l}.51 \\
6 *\end{array}$ & $.557^{* *}$ & .177 & .115 & 493 & .008 & .085 & -.164 & -.336 & .262 & -.219 & $\frac{-007}{-.007}$ & -.025 & .018 & .194 & .042 \\
\hline & $P$ & $\begin{array}{l}.025 \\
\end{array}$ & .146 & $\begin{array}{l}.00 \\
7\end{array}$ & .003 & .387 & .574 & $\begin{array}{l}.01 \\
1\end{array}$ & $\begin{array}{l}.970 \\
\end{array}$ & .679 & .423 & .093 & .195 & .282 & .973 & .905 & .929 & .343 & 8.839 \\
\hline & $\mathrm{N}$ & 26 & 26 & 26 & 26 & 26 & 26 & 26 & 26 & 26 & 26 & 26 & 26 & 26 & 26 & 26 & 26 & 26 & 26 \\
\hline \multirow[t]{3}{*}{$\mathrm{LI} / \mathrm{NB}$} & $\mathrm{R}$ & -.080 & -.251 & $\begin{array}{l}.01 \\
8\end{array}$ & -.301 & .042 & $\begin{array}{l}.196 \\
\end{array}$ & $\begin{array}{l}.31 \\
6\end{array}$ & $\begin{array}{l}.069 \\
\end{array}$ & .340 & -.089 & .227 & .111 & .032 & .321 & .280 & $-.428^{\prime \prime}$ & .229 & -.204 \\
\hline & $P$ & $\begin{array}{l}.699 \\
\end{array}$ & .215 & $\begin{array}{l}.92 \\
9\end{array}$ & $\begin{array}{l}.136 \\
\end{array}$ & .839 & .338 & $\begin{array}{l}.11 \\
5\end{array}$ & $\begin{array}{l}.738 \\
\end{array}$ & .089 & .665 & .264 & .588 & .876 & .110 & .166 & $\begin{array}{l}.029 \\
\end{array}$ & .260 & .317 \\
\hline & $\mathrm{N}$ & 26 & 26 & 26 & 26 & 26 & 26 & 26 & 26 & 26 & 26 & 26 & 26 & 26 & 26 & 26 & 26 & 26 & 26 \\
\hline \multirow[t]{3}{*}{$\begin{array}{l}\mathrm{L} / \mathrm{NB} \\
\mathrm{mm}\end{array}$} & $\mathrm{R}$ & .128 & -.324 & $\begin{array}{l}.23 \\
9\end{array}$ & .005 & .536 & -.020 & $\begin{array}{l}.35 \\
1\end{array}$ & -.599 & .311 & -.107 & .131 & .000 & -.150 & .238 & .288 & -384 & .057 & -.289 \\
\hline & $P$ & .533 & .106 & $\begin{array}{l}.24 \\
0\end{array}$ & .981 & $\begin{array}{l}.005 \\
\end{array}$ & .923 & $\begin{array}{l}.07 \\
9\end{array}$ & .001 & .122 & .602 & .524 & 1.000 & .464 & .242 & .154 & .053 & .782 & .152 \\
\hline & $\mathrm{N}$ & 26 & 26 & 26 & 26 & 26 & 26 & 26 & 26 & 26 & 26 & 26 & 26 & 26 & 26 & 26 & 26 & 26 & 26 \\
\hline \multirow[t]{3}{*}{$\overline{\text { IMPA }}$} & $\mathrm{R}$ & -.066 & .143 & $-\overline{114}$ & -.208 & .122 & .141 & $\begin{array}{l}.30 \\
8\end{array}$ & .133 & .046 & -.302 & .167 & -386 & $.580^{\prime \prime \prime}$ & $.405^{\prime \prime}$ & $.395^{\prime \prime}$ & $.503^{* * *}$ & -.186 & -.332 \\
\hline & $P$ & .750 & .487 & $\begin{array}{l}.58 \\
0\end{array}$ & .309 & .552 & .492 & $\begin{array}{l}.12 \\
6\end{array}$ & $\begin{array}{l}.518 \\
\end{array}$ & .823 & .134 & .414 & .051 & .002 & .040 & .046 & .009 & .363 & $\begin{array}{l}.097 \\
\end{array}$ \\
\hline & $\mathrm{N}$ & 26 & 26 & 26 & 26 & 26 & 26 & 26 & 26 & 26 & 26 & 26 & 26 & 26 & 26 & 26 & 26 & 26 & 26 \\
\hline $\begin{array}{l}\text { INTERI } \\
\text { NCISA }\end{array}$ & $\mathrm{R}$ & -.401 & -.219 & 293 & .387 & $-501^{* *}$ & $\begin{array}{l}.012 \\
\end{array}$ & $\begin{array}{l}.18 \\
8\end{array}$ & .412 & 246 & .228 & $\begin{array}{l}188 \\
\end{array}$ & -.076 & .042 & -.018 & -.097 & $\begin{array}{l}.149 \\
\end{array}$ & $\begin{array}{l}.050 \\
\end{array}$ & .154 \\
\hline L & $P$ & .042 & .281 & $\begin{array}{l}.14 \\
6\end{array}$ & .051 & .009 & .953 & $\begin{array}{l}.35 \\
7\end{array}$ & $\begin{array}{l}.036 \\
\end{array}$ & .226 & .263 & .358 & .712 & .839 & .930 & .639 & .467 & $\begin{array}{l}.808 \\
\end{array}$ & .452 \\
\hline & $\mathrm{N}$ & 26 & 26 & 26 & 26 & 26 & 26 & 26 & 26 & 26 & 26 & 26 & 26 & 26 & 26 & 26 & 26 & 26 & 26 \\
\hline
\end{tabular}




\section{REFERENCES}

1. Burstone, C. J. (1967). Lip posture and its significance in treatment planning. American journal of orthodontics, 53(4), 262-284.

2. Bergman, R. T., Waschak, J., Borzabadi-Farahani, A., \& Murphy, N. C. (2013). Longitudinal study of cephalometric soft tissue profile traits between the ages of 6 and 18 years. The Angle Orthodontist, 84(1), 48-55.

3. Holdaway, R. A. (1983). A soft-tissue cephalometric analysis and its use in orthodontic treatment planning. Part I. American journal of orthodontics, 84(1), 1-28.

4. Holdaway, R. A. (1984). A soft-tissue cephalometric analysis and its use in orthodontic treatment planning. Part II. American journal of orthodontics, 85(4), 279-293.

5. Riedel, R. A. (1950). Esthetics and its relation to orthodontic therapy. The Angle Orthodontist, 20(3), 168-178.

6. Riedel, R. A. (1957). An analysis of dentofacial relationships. American Journal of Orthodontics and Dentofacial Orthopedics, 43(2), 103-119.

7. Burstone, C. J. (1958). The integumental profile. American journal of orthodontics, 44(1), 125.

8. Park, Y. C., \& Burstone, C. J. (1986). Soft-tissue profile-fallacies of hard-tissue standards in treatment planning. American Journal of Orthodontics and Dentofacial Orthopedics, 90(1), 52-62.

9. Subtelny, J. D. (1959). A longitudinal study of soft tissue facial structures and their profile characteristics, defined in relation to underlying skeletal structures. American Journal of Orthodontics, 45(7), 481-507.

10. Mirabella, D., Bacconi, S., Gracco, A., Lombardo, L., \& Siciliani, G. (2008). Upper lip changes correlated with maxillary incisor movement in 65 orthodontically treated adult patients. World journal of orthodontics, 9(4).

11. Scott Conley, R., \& Jernigan, C. (2006). Soft tissue changes after upper premolar extraction in Class II camouflage therapy. The Angle Orthodontist, 76(1), 59-65.

12. Oliver, B. M. (1982). The influence of lip thickness and strain on upper lip response to incisor retraction. American journal of orthodontics, 82(2), 141-149.

13. Utsuno, H., Kageyama, T., Uchida, K., Yoshino, M., Miyazawa, H., \& Inoue, K. (2010). Facial soft tissue thickness in Japanese children. Forensic science international, 199(1-3), 109-e1.

14. Utsuno, H., Kageyama, T., Uchida, K., Yoshino, M., Oohigashi, S., Miyazawa, H., \& Inoue, K. (2010). Pilot study of facial soft tissue thickness differences among three skeletal classes in Japanese females. Forensic science international, 195(1-3), 165-e1.
15. Kamak, H., \& Celikoglu, M. (2012). Facial soft tissue thickness among skeletal malocclusions: is there a difference?. The Korean Journal of Orthodontics, 42(1), 23-31.

16. Hwang, H. S., Kim, W. S., \& McNamara Jr, J. A. (2002). Ethnic differences in the soft tissue profile of Korean and European-American adults with normal occlusions and well-balanced faces. The Angle Orthodontist, 72(1), 72-80.

17. Ioi, H., Nakata, S., Nakasima, A., \& Counts, A. L. (2007). Comparison of cephalometric norms between Japanese and Caucasian adults in anteroposterior and vertical dimension. The European Journal of Orthodontics, 29(5), 493-499.

18. Shindoi, J. M., Matsumoto, Y., Sato, Y., Ono, T., \& Harada, K. (2013). Soft tissue cephalometric norms for orthognathic and cosmetic surgery. Journal of Oral and Maxillofacial Surgery, 71(1), e24-e30.

19. Hoffelder, L. B., de Lima, E. M. S., Martinelli, F. L., \& Bolognese, A. M. (2007). Soft-tissue changes during facial growth in skeletal Class II individuals. American Journal of Orthodontics and Dentofacial Orthopedics, 131(4), 490-495.

20. Kim, K. H., Choy, K. C., \& Yun, H. S. (2002). Cephalometric analysis of skeletal Class II malocclusion in Korean adults. The korean journal of orthodontics, 32(4), 241-255.

21. Blanchette, M. E., Nanda, R. S., Currier, G. F., Ghosh, J., \& Nanda, S. K. (1996). A longitudinal cephalometric study of the soft tissue profile of short-and long face syndromes from 7 to 17 years. American journal of orthodontics and dentofacial orthopedics, 109(2), 116-131.

22. Macari, A. T., \& Hanna, A. E. (2013). Comparisons of soft tissue chin thickness in adult patients with various mandibular divergence patterns. Angle Orthodontist, 84(4), 708-714.

23. Karlsen, A. T. (1995). Craniofacial growth differences between low and high MP-SN angle males: a longitudinal study. The Angle Orthodontist, 65(5), 341-350.

24. Kang, C. S., Kim, K. H., \& Choy, K. C. (2000). The vertical changes of the lip and perioral soft tissue resulting from incisor retraction. Korean Journal of Orthodontics, 30(2), 185-196.

25. Legan, H. L., \& Burstone, C. J. (1980). Soft tissue cephalometric analysis for orthognathic surgery. Journal of oral surgery (American Dental Association: 1965), 38(10), 744-751.

26. Dahlberg, G. (1940). Statistical methods for medical and biological students. Statistical methods for medical and biological students.

27. Peck, S., Peck, L., \& Kataja, M. (1992). The gingival smile line. The Angle Orthodontist, 62(2), 91-100.

28. Yoon, Y. J. (2001). An epidemiologic study on the orthodontic patients who visited Department of Orthodontics, Chosun University Dental Hospital 
last 10 years (1990-1999). Korean Journal of Orthodontics, 31(2), 283-300.

29. Isaacson, J. R., Isaacson, R. J., Speidel, T. M., \& Worms, F. W. (1971). Extreme variation in vertical facial growth and associated variation in skeletal and dental relations. The Angle Orthodontist, 41(3), 219-229.

30. Schudy, F. F. (1964). Vertical growth versus anteroposterior growth as related to function and treatment. The Angle Orthodontist, 34(2), 75-93.

31. Creekmore, T. D. (1967). Inhibition or stimulation of the vertical growth of the facial complex, its significance to treatment. The Angle Orthodontist, 37(4), 285-297.

32. Sung, J. O., Kyung, H. M., Kwon, O. W., \& Sung, J. H. (1989). Cephalometric norms for orthognathic surgery. Korean Journal of Orthodontics, 19(1), 169-185.

33. Al-Hamdany, A. K. (2007). Integumental lips' height and separation in different Angle's classes of malocclu-sions. Al-Rafidain Dental Journal, (5), 38-49.

34. Chung, C. H., \& Mongiovi, V. D. (2003). Craniofacial growth in untreated skeletal Class I subjects with low, average, and high MP-SN angles: a longitudinal study. American journal of orthodontics and dentofacial orthopedics, 124(6), 670-678.
35. Chung, C. H., \& Wong, W. W. (2002). Craniofacial growth in untreated skeletal Class II subjects: a longitudinal study. American journal of orthodontics and dentofacial orthopedics, 122(6), 619-626.

36. Angle, E. H. (1899). Classification of malocclusion. Dent. Cosmos. 41, 350-375.

37. Subtelny, J. D. (1961). The soft tissue profile, growth and treatment changes. The Angle Orthodontist, 31(2), 105-122.

38. Von Dorsche, S. H., Fanghänel, J., KubeinMeesenburg, D., Nägerl, H., \& Hanschke, M. (1999). Interpretation of the vertical and longitudinal growth of the human skull. Annals of Anatomy-Anatomischer Anzeiger, 181(1), 99-103.

39. Phillips, V. M., \& Smuts, N. A. (1996). Facial reconstruction: utilization of computerized tomography to measure facial tissue thickness in a mixed racial population. Forensic Science International, 83(1), 51-59.

40. Aulsebrook, W. A., Becker, P. J., \& İşcan, M. Y. (1996). Facial soft-tissue thicknesses in the adult male Zulu. Forensic science international, 79(2), 83-102.

41. Hashim, H. A., \& AlBarakati, S. F. (2003). Cephalometric soft tissue profile analysis between two different ethnic groups: a comparative study. $J$ Contemp Dent Pract, 4(2), 60-73. 